6. Маркези Г. Джузеппе Верди. Г. Маркези. Опера. - М. : Музыка, 1990. C. $148-180$.

7. Орджоникидзе Г. Оперы Верди на сюжеты Шекспира. М.: Музыка, 1967. $325 \mathrm{c}$.

\title{
REFERENCES
}

1. Bogoyavlenskii, S. (1964). Verdi and Shakespeare // Shakespeare and music. L.: Music, P. 109-170 [in Russian].

2. Vasina-Grossman, V. (1978). Recitative // Musical Encyclopedia. M.: Music, V. 4. Stlb 605 [in Russian].

3. Verdi, J. (1973). Selected Letters [Ed. 2nd]. L.: Music [in Russian].

4. Vilner, N., Dvorkina, M. (1989). How to sing Verdi? // Soviet music. P. 44-49 [in Russian].

5. Krechmar, G. (1925). Opera History / ed. and with foreword. I. Glebova. L.: Academia [in Russian].

6. Marchesi, G. (1990). Giuseppe Verdi // G. Marchesi. Opera. M.: Music. P. 148-180 [in Russian].

7. Ordzhonikidze, G. (1967). Opera Verdi on the plots of Shakespeare. M.: Music [in Russian].

Стаття надійщла до редакції 21.06.2017

УДК 782.1/781.68 +784.3

DOI: $10.31723 / 2524-0447-2017-25-76-87$

\author{
Чжсан Івен \\ https://orcid.org/0000-0002-0495-1503 \\ здобувач кафедри історії музики \\ та музичної етнографії \\ ОНМА ім. А. В. Нежданової \\ OdZhangYiwen@gmail.com
}

\section{ОПЕРНА ТВОРЧІСТЬ ДЖ. ПУЧЧІНІ ЯК ФЕНОМЕН ПІЗНЬОРОМАНТИЧНОГО РОЗУМІННЯ ТЕМИ «ВІЧНО ЖІНОЧНОГО»}

\footnotetext{
Мета статті - виявити притаманні Дж. Пуччіні тенденції інтерпретації жіночих образів в опері, виявити їх сталу естетичну складову як ідеалізацію образу, найбільш характерні стилістичні мовні показники. Методологія роботи визначається синтезом жанрово-естетичного та стилістичного підходів, орієнтована $і$ на аналітичне поглиблення, $i$ на ціннісні узагальнення. Наукова новизна статті полягає у виявленні складної жканрової контамінації як основи оперного методу Пуччіні, що безпосередньо реалізується в образах жіночих персонажів (на прикладі 
образу Мімі з «Богеми»). Висновки статті дозволяють стверджувати, що ідеалізоване піднесення образу відбувається в опері разом з підсиленням мелодраматичного начала, засобів виразовості, притаманних мелодрамі. Загострюючи трагедійну інтенцію образу, вони виводять його за межі сюжетної композиції до культурно-семантичного простору «вічних персоніфікацій ідеї жертовного кохання.

Ключові слова: стиль Дж. Пуччіні, мелодрама, трагічне, оперний образ, жертовне кохання.

Zhang Yiwen, applicant of the Department of Music History and musical ethnography ONMA them. A. V. Nezhdanova

J. Puccini's opera works as a phenomenon of late romantic understanding of the theme «eternally feminine»

The purpose of the article is to reveal the tendencies of the interpretation of female images in the J. Puccini's opera, to reveal their aesthetic constituent as an idealization of the image, the most characteristic stylistic linguistic indices. The methodology of work is determined by the synthesis of genre-aesthetic and stylistic approaches, oriented both on analytical deepening, and on value generalizations. The scientific novelty of the article is the discovery of complex genre contamination as the basis of the opera method of Puccini, which is directly implemented in the images of female characters (on the example of the image of Mimi from «Bohemia»). The conclusions of the article suggest that the idealized elevation of the image takes place in the opera together with the amplification of the melodramatic origin, the means of expression, inherent in the melodrama. Closing the tragic intentions of the image, they bring him beyond the limits of the plot composition to the cultural-semantic space of «eternal» personification of the idea of sacrificial love.

Keywords: J. Puccini's style, melodrama, tragic, opera image, sacrificial love.

Чжан Ивен, соискатель кафедры истории музыки и музыкальной этнографии ОНМА им. А. В. Неждановой

Оперное творчество Дж. Пуччини как феномен позднеромантического понимания темы «вечно женственного»

Цель статьи - выявить присущие Дж. Пуччини тенденции интерпретации женских образов в опере, выявить их постоянную эстетическую составляюшую как идеализацию образа, наиболее характерные стилистические языковые показатели. Методология работы определяется синтезом жанрово-эстетического и стилистического подходов, ориентирована и на аналитическое углубление, и на ценностные обобщения. Научная новизна статьи заключается в выявлении сложной жанровой контаминации как основы оперного метода Пуччини, которая непосредственно реализуется в образах женских персонажей (на примере образа Мими из «Богемы»). Выводы статьи позволяют утверждать, 
что идеализированный подбем образа происходит в опере вместе с усилением мелодраматического начала, средств выразительности, присущих мелодраме. Обостряя трагедийную интенцию образа, они выводят его за пределы сюжетной композиции в культурно-семантическое пространство «вечных» персонификаций идеи жертвенной любви.

Ключевые слова: стиль Дж. Пуччини, мелодрама, трагическое, оперный образ, жертвенная любовь.

Актуальність теми дослідження зумовлена тим, що дотепер залишається нез'ясованим особливий образний план оперної творчості Дж. Пуччіні, утворюваний жіночими персонажами та спрямований до найвищої емоційної експресії, тому зумовлюючий і специфічні музично-інтонаційні, сценічно-дійові ефекти. Вплив жіночих образів на формування естетичної ідеї та цілісного стильового рішення в операх цього композитора залишається не лише відкритим, а й не повною мірою сформульованим, визначеним питанням. Мета нашої статті - виявити притаманні Дж. Пуччіні тенденції інтерпретації жіночих образів в опері, виявити їх сталу естетичну складову як ідеалізацію образу, найбільш характерні стилістичні мовні показники.

У зв'язку з цим в статті пропонується звернення до жанрової природи та специфічних виразових показників мелодрами, як того компонента оперної поетики, що стає іiі визначальним естетикопсихологічним показником, відкриває головне призначення їі персонажів - як умовних «героїв» оперної дії, що сама має високий рівень художньо-змістової умовності (про це, як і про певні аспекти історії мелодрами: [3; 4]).

Основний зміст роботи. Термін «мелодрама» має декілька значень, оскільки застосовується до різних видів театральної драми, а на їі засадах, сполучаючись з певними художніми формами та їх виразовими можливостями, виокремлюється як досить автономна естетична парадигма. У буквальному перекладі із грецького мелодрама (від melos - «музика» i drama - «дія») означає музично-драматичну дію, виражену засобами музики або у зв'язку з музичними засобами. У такому значенні слово «мелодрама» вживалося в Італії (і почасти у Франції) в XVII-XVIII ст. як синонім опери, але розумілося, однак, не стільки як музичний, скільки як літературний, поетичний жанр. У цьому змісті італійські літературознавці дотепер говорять про Метастазіо як про «майстра мелодрами».

Друге значення термін «мелодрама» одержав у другій половині XVIII ст. у Франції для позначення особливого роду п’єсок з однією 
або двома діючими особами (звідси найменування їх також монодрамами або дуодрамами), декламація яких супроводжувалася музикою, що заповнювала також перерви між ліричними монологами. Зразком такої мелодрами вважається «Пігмаліон» (1762) Ж. Ж. Руссо.

Ще інше значення термін «мелодрама» одержав у роки Директорії у Франції для позначення авантюрної театральної історії з раптовими гострими сценічними положеннями й з піднесеним емфатичним стилем. 3 мелодрамою типу «Пігмаліона» іiі зближала тільки наявність музики, що сповіщала про наближення сумних або патетичних ситуацій тривожним тремоло, що підсилювали емоційну напруженість дії. Спочатку відіграючи досить важливу роль у п’єсах цього жанру, що зародився в бульварних театрах передреволюційного Парижа, ці музичні інтерлюдії самі називалися мелодрамами, що й дали назву всьому жанру; згодом вони відійшли до ролі другорядного моменту й поступово атрофувалися. Тоді термін став застосовуватися до п'єс, позбавлених музичного супроводу, але відповідних хоча б частково структурі того конкретно-історичного жанру, який склався у Франції в останні роки XVIII ст. [2].

Законність подібного звуження поняття мелодрама випливає з тієї обставини, що перехід від першого значення терміна до другого й третього зовсім не означав трансформації якогось єдиного жанру, а навпаки - з різних театрально-ситуативних джерел випливали ще хаотичні та не зібрані докупи ознаки, що передбачали єдину жанрову форму, але поки що фіксували різні за видовою та семантичною сутністю явища.

У цілому, мелодрама, проходячи досить довгий шлях історичного формування, постає жанрово-семантичною галуззю мистецтва, що володіє самостійною естетичною настановою на певний тип міжособистісних (суб'єктно-суб'єктних) відносин і діалогічних переживань, що залучають і афектовані способи самовираження, самооцінки.

Мелодрама поєднує в собі драматичний і ліричний досвід, указує на ті ситуації, психологічні відносини, коли виникає певна протидія між зовнішніми обставинами і внутрішніми установками суб'єкта, але ця протидія може бути розв'язаною в кожній зі сторін. Суб'єкту надані право й можливість змінити свою установку, розібратися в собі самому, співпережити собі самому й відкрити у собі внутрішні сили; зовнішні обставини також допускають подібні зміни.

Головна відмінність мелодрами від трагедії полягає в тому, що вона пропонує щасливий кінець. Щасливий кінець у трагедії - навіть припущення його можливість - знищує трагедійний ефект. Мелодрамі ж 
не потрібна загибель кращого з героїв - на відміну від трагедії. Вона скоріше навіть розбудовує інстинкти й практику самозбереження й виживання особистості, у тому числі зміцнюючи досвід емоційного реагування, і заради цього підсилює свій музичний бік. Але в опері мелодраматичний тонус здатен переважати навіть тоді, коли головний герой (один з головних персонажів) вмирає, гине, йде з життя: форма, у якій це відбувається, знімає гостроту переживання як трагедійного, трагічний ефект пом'якшується ліричною емоцією, що створюється музично-звучним шляхом.

Парність головних персонажів, зумовлена провідною темою кохання, дозволяє авторам опер, зокрема Пуччіні, обирати жіночий образ як жертовний, що несе ноту високого трагізму, але розчиняє іiї у наданій іншому - суб'єкту по оперному естетичному діалогу досягти благополуччя й продовження існування. Трагічна інтенція виникає як лінія зв’язку між двома оперними персоналіями, але вирішити іiі, досягти іiі здійснення та спокутування трагічної провини насмілюється лише один з них, вірніше - одна, адже здатною на трагічний вчинок в операх Пуччіні виявляється саме жінка. Такими є Тоска, Ліу, Чіо-Чіо-Сан; такою, хоча і в дещо більш «приземленому» сюжетному втіленні, але значно підвищеному порівняно з літературним першоджерелом, постає Мімі в опері «Богема». Власне цей персонаж розпочинає галерею зрілих оперних жіночих образів Пуччіні, свідчить про досягнення ним сталих авторських стильових координат [1].

Обов'язковим атрибутом мелодрами є досить переконливе тривале розкриття емоційного стану персонажа, досвіду переживання. Саме так вноситься в мелодраму ліричний компонент. Довготриваюча індивідуальна емоція, мотивація сюжету з боку особистісного переживання, можливість поринути в це переживання й відкрити для себе його красу є необхідними моментами мелодрами.

Саме тому еквівалентом мелодрами в музичному мистецтві $є$ оперна мелодичність; як мелодрама опера виправдовує очікування саме завдяки своєму мелосу, мелодичним надбанням. На мелодичній основі оперна мелодрама пов’язує психологічні можливості людини, насамперед досвід переживання, з вчинками, здатністю включатися до подієвого життєвого процесу. Таким шляхом мелодрама поєднує ідеальний і реальний людські світи, не залишаючись у жодному з них назавжди, але вказуючи на можливості переходу з одного в іншій, у чому й полягає іiі власна змістова діалогічність. Таким чином мелодрама впливає на формування «високого» жанру західноєвропейського теа- 
тру першої половини XIX ст. - романтичної драми, а усі основні риси романтичного стилю знаходять яскраве вираження в мелодрамі періоду ї̈ розквіту.

Мелодраматичність та оперний ліризм - майже синонімічні поняття. Головною стороною оперного впливу є лірична, що виявляє нові можливості міжособистісної емоційної співпричетності. Як найбільш соціально затребуваний вид музично-виконавської творчості, оперна лірика одночасно імпліцитно є присутньою в епічній та драматичній жанрових театральних формах - завдяки вираженню в них, тим або іншим способом, особистісного начала, у тому числі авторської особистості; оперна поетика спрямована на виявлення й художнє втілення найбільш важливих для людського існування спільних процесів «щиросердечного життя», тобто тих інтимно-психологічних проявів особистісної свідомості, які свідчать про соціально-історичну обумовленість особистісної неповторності. Тому можна стверджувати, що саме ліричним шляхом в оперному мистецтві створюється історично-епохальний типовий образ сучасника, який відповідає «великим» рухам культури - «великому часу» культурної людської свідомості.

Якщо вже ліричне слово з'являється «концентратом поетичності» (Л. Гінзбург), сила впливу якого нарощується багатовіковою традицією збереження й передачі загальнозначущих культурних цінностей, то ще більшим смисловим тезаурусом володіє музична форма, що узагальнює й специфічними логічними засобами втілює семантичні домінанти культури.

Опорні етапи формування музично-текстової семантики дозволяють стверджувати, що жанрове призначення оперної форми обумовлене ії перехідним положенням щодо трьох основних рівнів музики як автономного текстологічного феномена: ораторіальності, моторності й мелодійності. Багатоскладовість мелодійної сфери музики пояснюється іiї історичними передумовами та психологічним призначенням, а оперна форма стає найбільш розвиненою і масштабною жанровою основою іїі втілення. Тому в загальному плані оперний мелос, що визначає мову оперних героїв, можна розглядати як певну мовленнєву сферу музики, що створюється шляхом накопичення словесно-музичних фігур та їх взаємодії-інтеграції, що веде до виникнення нових мелодраматичних поєднань.

Зазвичай оперний вокальний мелос, що обирає переважно сольно-ансамблеву форму висловлення, націлений на вираження осо- 
бистісного «Я», яке завжди є відображенням діалогічних взаємин персонажа з навколишнім. Усі музично-мелодичні синтагми, що сприяють цьому секумлоквіуму, утворюють лірико-мелодраматичну образну сферу, сформовані довгостроковим спілкуванням словесних і музичних логоформ, представляють здатність оперного сюжету розбудовуватися на тлі заглиблено ліричного й лірико-драматичного словесно-музичного тексту, створюючи власний «уявний світ», іншу художньо-подієву реальність.

Специфіку лірично-мелодраматичного змісту опери можна визначити як усвідомлення індивідуально-творчого ставлення до «мовної пам'яті» жанру, як поетичного, так і музичного, мета якого - формування автономної оперної «стильової пам'яті», а також висвітлення природи мелодрами - явища, яке безпосередньо здійснює ліричну взаємодію слова і музики.

Набуваючи провідну роль у становленні музичного театру та впливаючи на смислові устремління опери, мелодрама врівноважує трагедійний і утопічний ціннісні полюси світосприймання, дозволяє вигаданій ідеалізованій реальності вдало замінити дійсне соціальне життя, підняти до доленосних значення конкретних вчинків окремих людей у певних життєвих обставинах, тобто - укрупнити, підняти існування окремої людини до рівня «заповідних» загальнолюдських змістів - до рівня оперного героя.

Так відбувається і в опері «Богема», аналіз образного змісту якої приводить до виділення таких іiі головних параметрів, як: відмінність трактування Пуччіні від літературного першоджерела (роману А. Мюрже «Сцени з життя богеми»); місце образа Мімі в композиційній системі опери, його взаємодія з образами «богеми», Рудольфа й Мюзетти; музично-драматургічні функції образа Мімі та його еволюція впродовж усієї опери; музично-інтонаційне вираження трагедійного змісту образа Мімі; типи інтонування та їх значення в музичній концепції опери; провідні музичні символи в опері «Богема».

На відміну від Мюрже, Пуччіні робить образ Мімі головним і провідним протягом всієї опери, свого роду «епіцентром» драматичної дії (подієвого ряду), відносин (ліричної сторони опери), переживань (експресивних кульмінацій). Тому цей образ має монотематичну основу, ій підкорюються окремі лейтмотиви цієї героїні (усього 5), які таким шляхом, розбудовуючись у контексті опери, стають символами - і не тільки долі Мімі, а й трагічної долі людини в цілому. Трагічна ідея опери: протистояння людини фатальній силі зовнішніх обста- 
вин і знаходження власної духовної сили, що перевершує долю, краса піднесеного переживання, що перетворює свідомість. Таким чином, Пуччіні успадковує античну модель трагічного з ії ефектом катарсису (основний ефект останньої сцени 4-ї діï), збагачуючи іiї «психологічним реалізмом» трагедійного театру шекспірівського типу.

Образ Мімі в опері розбудовується в безпосередньому зв'язку з образом Рудольфа та у більш далекому, опосередкованому зв'язку з образами «богеми». Рудольф стає посередником між світом богеми і ліричним світом Мімі, що виражається, у тому числі, в «змішаному» вокально-інструментальному характері його основного лейтмотиву. Розмежування тематизму опери на інструментальний і вокальний за типом інтонування дозволяє Пуччіні чітко відокремити сили дії нещадної до людині реальної дійсності - і сили контрдії - ліричного світу героїні, іiї особливого виміру дійсності як «мрії щастя» (слова 3 арії в 1 діï). Крім цього особливі семантичні функції формуються у кожного типу інтонування, у кожного жанрово-стилістичного прототипу - й таким шляхом Пуччіні досягає образної ясності, чіткості відносин, близької до літературної сюжетної логіки побудови музичного тексту опери.

Звернувшись до роману А. Мюрже, що складається з низки новел, Пуччіні значно переробляє його зміст та підсилює його єдність. По-перше, він сполучає дві сюжетні лінії: відносин Рудольфа й Мімі та відносин Жака й Франсини. Епізодичний сюжет «Муфти Франсини» (18-та глава роману) він поширює на всю лінію взаємин Мімі й Рудольфа, піднімаючи їх і надаючи їм трагічного характеру. Подруге, якщо в Мюрже єдиним, проведеним через усі новели, є образ Рудольфа (автобіографічний для Мюрже), то Пуччіні ставить поруч з ним образ Мімі, який поступово стає головним, підкоряючи собі всі інші, тому що $є$ свого роду «епіцентром» трагедії. Таким чином, Пуччіні змінює, піднімає, наділяє трагічними рисами сюжет Мюрже завдяки образу Мімі. Саме цей образ є носієм трагічного почуття, яке від Мімі передається іншим учасникам дії, але спочатку їм не притаманно. Мімі в опері «Богема» виявляється альтруїстично люблячою, жертовною особистістю, смерть якої вражає й перетворює увесь світ «богеми».

Відносини іiі з іншими персонажами відрізняються трьома головними особливостями. Ї̈̈ образ розкривається, насамперед, в ансамблевих сценах з Рудольфом, тобто є діалогічним стосовно Рудольфа. Рудольф для неї, з одного боку, найбільш близький співзвучний пер- 
сонаж, у спілкуванні з яким вона усвідомлює свою долю, своє призначення; це виражається в музично-тематичному змісті опери. Образ Рудольфа є «дзеркальним» стосовно образа Мімі. Під впливом останнього образ Рудольфа набуває лірично-мелодраматичних рис в першій дії, драматизується в третій, досягає трагічної вершини в четвертій. 3 іншого боку, Рудольф стає для Мімі провідником у світ «богеми», що особливо явно відкривається в другій дії. На відміну від Мюрже, у якого Мімі сама була невід’ємною частиною богемного життя, в опері ії̈ музична мова принципово відрізняється від музичних характеристик «богеми». Особливо контрастною є рухлива танцювальна «вальсоподібна» характеристика Мюзетти.

Для музичної мови «богеми» типовими стають інструментальні й танцювальні побудови. Музична мова Мімі відрізняється від них не тільки вокальним інтонаційним походженням, але й різноманітністю способів мелодичного інтонування. Така різноманітність дозволяє музично розкрити еволюцію образа Мімі. Тому якщо для миру «богеми», включаючи Рудольфа, характерний лейтмотивний принцип, тобто наявність стійких повторюваних характеристик, свого роду «візитівок» (музичних емблем) героїв, то для сфери Мімі опорним стає монотематичний принцип, який підкоряє собі й лейтмотивні прийоми. Саме з ії образом пов'язаний розвиток «теми долі», елементи якої накопичуються в тексті опери, а повною мірою ця тема проявляється в третій дії та у другій половині четвертої дії (у сцені смерті Мімі). Щодо цього «Богему» можна вважати першою оперою, у якій значення теми долі виявилося вже повною естетичною мірою.

Музично-драматургічні функції образа Мімі визначаються тим, що він стає центром притягування основного тематизму опери й стрижнем музичного сценарію. Якщо в інших персонажів опери - по одній музичній характеристиці, то в партії Мімі виділяються 5 провідних тем, скоріше лейтмотивів, оскільки кожний з них дуже лаконічний. Перший з них з'являється на самому початку сцени Рудольфа й Мімі в першій дії й може бути названий «темою імені» (звучить на словах «Мене кличуть Мімі). Другий відкриває комплекс «фатальних тем», будучи «темою хвороби» Мімі. Особливого значення набуває третій лейтмотив з характерним секвенційним ходом, який провіщає тему останнього «прощального» аріозо Мімі з 4 діі. Він відрізняється плавністю, інтонацією оспівування терції, одночасно ритмічною рівністю, простотою. Цікаво відзначити, що цей мотив повторюється в партії Рудольфа, який у такий спосіб «вторить» Мімі. 4-й лейтмо- 
тив можна назвати «темою життя» або «мрії про щастя» (з'являється в першій дії на словах «Мені подобається робота...»); у семантичному плані він двоїстий. 3 одного боку, це аріозна кантилена з опорою на всі ті ж типові для образа терцові інтонації. Його пожвавлюють тріольні побудови - загальна стилістична риса партій Рудольфа й Мімі, знак збудження, хвилювання, у деяких випадках - тривоги. Цікаво відзначити, що в «темі кохання», що пролунала в партії Рудольфа незадовго до появи 4-го лейтмотиву Мімі, також виникає опора на терцову інтонацію, за будовою й характером він близький «темі мрії про щастя». Можна припустити, що в такий спосіб Пуччіні показав, що почуття Рудольфа має адресата, воно пробуджене Мімі і є іï своєрідним відбиттям, а «тема кохання» стає ії̈ непрямою характеристикою, у всякому разі органічно входить до комплексу ліричних тем Мімі. Відзначимо, що Пуччіні $є$ майстром і колективних групових портретів (образ «богеми»), і деталізованих психологічних характеристик, тобто й «великого», i «дрібного» штриха. За допомогою однієї стилістичної деталі, наприклад, тріолі, тремоло, пунктирного ритму, тритонового ходу, він створює напрямок розвитку образа, наділяє його тематичною значимістю. Навіть так звані фонові засоби набувають у музичному тексті опери Пуччіні образну вагомість, характеристичність, самостійні знакові функції. Так, у партії Мімі особу семантичну функцію має «тиха» динаміка, тобто використання РР, РРР, РРРР. Ї̈̈ образ супроводжує особлива «тиша», яка набуває трагічного значення в останньому, найбільш буквально мелодраматичному, епізоді опери (у сцені смерті Мімі). 4-й лейтмотив Мімі, тобто «тема життя» у цій сцені пролунає на РРРР, стаючи «темою відходу», небуття, зникнення...

Протилежна, гучна динаміка (FF, FFF) виражає найчастіше розпач, біль, протест або позначає експресивні мелодійні кульмінації, вищу експресію почуття. Також на закінчення аріозо з 1-ї дії Пуччіні вводить до партії Мімі вокально-речитативну скоромовку, що межує зі словесною вимовою; вона хоч і мелодизована, але наближена до «натурального» висловлення, і цей тип інтонування, що виник у партії Мімі, знайде подальший розвиток в 3-й і 4-й діях. Підкреслюючи аффективну кульмінацію трагедії, Пуччіні вводить у партію Рудольфа «напівспів напівговір», прийом Sprechstimme, тобто основний мелодраматичний - мелодекламаційний - прийом.

В 4-й дії з'являються ще кілька варіантів теми прощального аріозо Мімі. Можна сказати, що в опері розбудовується монотематичний «комплекс прощання» В 3-й дії до нього відносяться «мотив 
холоду» і «мотив втоми». Для «мотиву холоду» характерні квартові ходи, акордовий склад вертикалі, посилення декламаційних інтонацій у мелодії. Ці стилістичні риси стають показовими для комплексу прощання. Мотив холоду витриманий у манері речитації в партії Рудольфа, звучить на тлі тріольного мотиву хвилювання, веде до появи хроматичних ходів - як у вокальній партії, так і в оркестровій. Подібні хроматичні ходи будуть звучати в сцені смерті Мімі. Важливо відзначити, що образний зміст музичної теми розкривається в супутній ій словесній репліці. Слово допомагає Пуччіні уточнювати значення музичного прийому й формувати його символічні функції.

Прощальне аріозо Мімі концентрує стилістику всіх мотивів долі. Не випадково в партії Мімі в цій останній сцені найбільш відкрито протистоять одна одній дві теми: «тема життя» і «тема прощання». Після глибокого занурення в тишу катарсису тема аріозо знову пролунає, але вже як протест проти того, що трапилося - tutti FFF (суто мелодраматичний ефект вигуку).

Узагальнюючи, відзначимо, що наукова новизна статті полягає у виявленні складної жанрової контамінації як основи оперного методу Пуччіні, що безпосередньо реалізується в образах жіночих персонажів (на прикладі образу Мімі з «Богеми»).

Висновки статті дозволяють стверджувати, що ідеалізоване піднесення образу відбувається в опері разом з підсиленням мелодраматичного начала, засобів виразовості, притаманних мелодрамі. Загострюючи трагедійну інтенцію образу, вони виводять його за межі сюжетної композиції до культурно-семантичного простору «вічних» персоніфікацій ідеї жертовного кохання.

\section{СПИСОК ЛІТЕРАТУРИ}

1. Ливанова Т. История западноевропейской музыки до 1789 г.: в 2 т. М.: Музыка, 1983. Т. 1.462 с.

2. Литературная энциклопедия. URL: http://dic.academic.ru/contents.nsf/ enc literature

3. Чжу Лу. Между трагедией и утопией: типологические черты русской музики второй половины XIX века. Музичне мистецтво і культура: науковий вісник ОДМА ім. А. В. Нежданової. Одеса: Друкарський дім, 2011. Вип. 13. C. $320-328$.

4. Чжу Лу. Лирические интенции музыкальной символики в оперном творчестве композиторов XIX века. Музичне мистецтво $і$ культура: науковий вісник ОДМА ім. А. В. Нежданової. Одеса: Друкарський дім, 2011. Вип. 14. С. $253-262$. 
5. Шестаков В. От этоса к аффекту. История музыкальной эстетики от античности до XVIII века. М.: Музыка, 1975. 352 с.

\title{
REFERENCES
}

1. Livanova, T. (1983). History of Western European music until 1789: in 2 volumes. Moscow: Music,. Vol. 1 Music [in Russian].

2. Literary encyclopedia: URL: http://dic.academic.ru/contents.nsf/enc_literature Music [in Russian].

3. Zhu, Lu. (2011). Between tragedy and utopia: the typological features of the Russian music of the second half of the XIX century // Music Art and Culture: Science Bulletin ODMA im. A. V. Nezhdanova. Odessa: Drukarsky House. № 13. P. 320-328 Music [in Russian].

4. Zhu, Lu. (2011). Lyrical intentions of musical symbolism in the 19th century composers' opera works // Music Art and Culture: Science Bulletin ODMA im. A. V. Nezhdanova. Odessa: Drukarsky House. № 14. P. 253-262 Music [in Russian].

5. Shestakov, V. (1975). From ethos to affect. The history of musical aesthetics from antiquity to the eighteenth century. M.: Music Music [in Russian].

Стаття надійшла до редакції 28.06.2017

УДК $78.01 / .08+782.1 / 784.95$

\author{
Ван Лунчуань \\ https://orcid.org/0000-0002-6702-4539 \\ здобувач кафедри історії музики \\ та музичної етнографії \\ ОНМА ім. А. В. Нежданової \\ OdWangLongchuan@gmail.com
}

\section{ОСОБЛИВОСТІ ОПЕРНОЇ СЮЖЕТОЛОГІЇ В ТВОРЧОСТІ РОСІЙСЫКИХ КОМПОЗИТОРІВ ХІХ СТОЛІТТЯ}

\begin{abstract}
Мета статті - виявити літературну інспірацію оперної сюжетології в творчості російських композиторів класичної доби, першочерговий вплив «пушкінського слова» на російську оперну поетику. Методологія роботи передбачає застосування філологічного та естетичного підходів y річищі оперознавчого. Наукова новизна полягає у розвитку категорії сюжетології на жанровому та композиційно-стилістичному музикознавчому рівнях. Запроваджується пізнавальне ставлення до оперного сюжету як до синергійного явища, що трансформує міжвидові художні взаємодії у нову музично-образну цілісність оперного тексту. Висновки. Літературна творчість найбільще зумовила відбір тем і сюжетів оперної творчості в російській музиці, однак критеріями втілення їх в музиці
\end{abstract}

(C) Ван Лунчуань, 2017 